doi: 10.7546/BL.LXVI.19.03.01

\title{
СЪВРЕМЕННИ ПРЕДИЗВИКАТЕЛСТВА ПРЕД НАЦИОНАЛНАТА И ЕВРОПЕЙСКАТА ДИАЛЕКТОЛОГИЯ
}

\author{
СЛАВКА КЕРЕМИДЧИЕВА \\ ИНСТИТУТ ЗА БЪЛГАРСКИ ЕЗИК „ПРОФ. ЛЮБОМИР АНДРЕЙЧИН“ ПРИ БАН \\ slavka_ker@abv.bg
}

Ако бяха верни футурологичните прогнози, които отдавна предизвестиха „изчезването“ на диалектите, тази книжка на сп. Български език нямаше да бъде факт. Нейната поява е поредното доказателство, че и в XXI век народните говори продължават да изпълняват своята функция като средство за комуникация на по-малки и по-големи общности, които - според изводите на авторитетни български и световни социолингвисти и диалектолози - не само че не изчезват в условията на глобализация, а напротив - консолидират се и запазват своя език и култура като белег за идентичността си. Това отваря нови перспективи и поставя нови задачи пред диалектологията и лингвистичната география.

По-голямата част от статиите на български и чуждестранни учени в посветения на диалектоложка проблематика брой на списанието са разработени предимно върху автентичен диалектен материал, събран на терен в последните години или буквално месеци. При това не само от български, но и от други славянски или неродствени диалекти.

Интересът към тази книжка ще бъде провокиран от обстоятелството, че проучванията обхващат всички езикови равнища: фонетика и фонология, морфология, словообразуване и лексика, а редица диалектни особености могат да се видят проектирани с методите на лингвистичната география не само върху българското, но и върху европейското езиково пространство.

Румънските учени Николае Сараманду и Мануела Невачи правят „Лингвистичен мотивационен анализ на балкански и романски характерни особености в Европейския лингвистичен атлас“, като илюстрират своите разсъждения с посочването на мотивационните признаци в различните названия на тетрадка, глухарче, дните на седмицата и пиявица, които се употребяват в балканските и романските диалекти.

Лучия Антонова-Василева също използва материали от Европейския лингвистичен атлас, за да представи „Названията за плашило в българските диалекти“, но за нуждите на своето проучване се позовава и на карти от Общчославянския лингвистичен атлас. Изследването е обогатено и с лексикален материал от Архива на Българския диалектен речник, както и със собствени материали.

Георги Митринов търси на всички езикови равнища „Български езикови следи в гръцкия говор на гр. Суфли (Западна Тракия)“ в публикувания в гръцки сайт (едно от съвременните проявления на диалектното) речников материал от български произход. Той доказва, че „близо 100 години след обезбълга- 
ряването му през първата половина на XX в.“" в говора на това селище още се пазят българските езикови черти.

Отрадна е появата на разработка на диалектоложка фонологична тема, рядко срещаща се в последните години. Младият учен Катерина Ушева има безспорен опит в тази област и в статията си „Фонетико-фонологична характеристика на говора на село Горно Драглище, Разложко“ прави прецизно описание на смесената фонологична (вокална - от източнобългарски, и консонантна - от западнобългарски тип) система на този оригинален и съхранен и до днес диалект от ятовата изоглосна област.

Статията на полския учен Йежи Шерочук „Диалектният речник като проявление на опазването на народната култура“ представя намиращите признание и в славистичната общност две концепции и техните методологически принципи, въз основа на които полските диалектни лексикографи в най-ново време изработват регионални речници на по-малки или по-големи общности.

Оперирайки с богат, лично събран диалектен материал, Елена КаневскаНиколова анализира от словообразувателна и лексикосемантична гледна точка „Турско-български хибридни съществителни имена за лица с пейоративно значение в смолянския говор“, като посочва морфологичните отлики между общобългарските и славянските nomina augmentativa et pejorativa, от една страна, и тези в смолянския говор - от друга.

C анализа на няколко диалектни имена на различни растения, които интерпретира в словообразувателен и семантичен план, Ана Кочева разглежда интересния проблем ,За семантичния срив при названията от народната ботаническа (дървесна) таксономия“. Най-многобройни са примерите, разкриващи съдържанието на истинския семантичен срив, с които авторката се опитва да въведе този термин в българската лингвистика.

Докторантката Ализа Халил предлага „Номинационна характеристика на понятията за видовете традиционни алкохолни напитки в българските социални говори“. Интересните примери, които се анализират със синхронно-диахронния метод, са от най-богатата лексика на зидарския говор, но има и термини от цигуларския, ботушарския и други социални диалекти.

В броя е представена втората част на разработката на Игнаций Долински „Още за обхвата на словообразувателната категория nomina instrumenti (NInstr) и за словообразувателните парафрази на дериватите със значение средство за действие

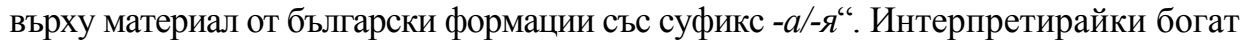
български материал, ерудираният българист прави мотивационен анализ на избрана група деривати, като специално отбелязва връзката между мотивация и деривация.

Конспективното изреждане на включените в тази книжка приносни статии, диктувано от жанра увод, може само да маркира разнообразната им тематика, подсказваща, че съвременната национална и европейска диалектология са изправени пред още много научни предизвикателства.

проф. д-р Славка Керемидчиева Секция за българска диалектология и лингвистична география Институт за български език „Проф. Л. Андрейчин“ при БАН бул. „Шипченски проход“ 52, бл. 17, 1113 София, България

Публикувано: 30 септември 2019 